\title{
The Study of The Meaning of Body Language and Perceptions of Audience Garuda Indonesia Television Commercials Hands Version
}

\author{
Ira Wirasari (1st Author) \\ Telkom University \\ irawirasari@telkomuniversity.ac.id
}

\author{
Rizky Indah (2nd Author) \\ Telkom University \\ rizkyindahsari@outlook.com
}

\begin{abstract}
Airline commercials rare in advertising industry in Indonesia. Garuda Indonesia as a national airline come up with an ads that using a combination of symbolic movements and traditional Indonesian dance as a form to deliver the message in advertising. This study aimed to understand the meaning of nonverbal signs that can be found in this ad and to understand perception of audience to the ad. This research used nonverbal semiotics and semiotics of Roland Barthes as basic theory to dissect the meaning behind the ad, and used perception theory to understand audience's perception of the ad. Methods and techniques that used in this research are qualitative descriptive method, study literature, and questionnaire. The results of this research are the meaning of nonverbal signs of the ad (1) describes the realization of the nature of unity, spirit, cohesiveness, cooperation, loyalty, trustworthiness, and sincerity in serving, (2) audience could understand the meaning of the advertisement. This research expected to provide an understanding to the meaning that implied in the ad thus the audience can be more easily to interpret nonverbal sign in the ad and understanding the message that the advertisers want to convey to the audience.
\end{abstract}

Keywords: Semiotics, nonverbal, message, advertising

\section{INTRODUCTION}

The development of the advertising world not only produces or sells daily needs products, but also promotes airlines. This is arguably a rare thing in Indonesia, because there are 13 scheduled commercial airlines in Indonesia and only 6 of the 13 airlines that use television advertising as a form of media promotion of their products. And among the 6 airlines, only 2 airlines have advertised with soft-sell approaches, namely: Garuda Indonesia with its advertisement titled "Hands" and Indonesia AirAsia with its advertisement entitled "People". (www.tiket2.com)

In the Garuda Indonesia television ad version, "Hands" carries the concept that passion and sincerity in serving, upholding ancestral values are the main thing. This is shown in the concept of the advertisement where there are Indonesian contemporary dance performances and displays the meaning of solid teamwork. In this advertisement, Garuda Indonesia would like to convey that there are thousands of hands behind the comfort of flight with Garuda Indonesia.

As quoted in the Colors-Garuda Indonesia Inflight Magazine, Dimas Djayadiningrat as the director of this advertisement stated "The unique thing about this new TVC campaign is the fact that we record these images as contemporary performing arts and work directly with Garuda Indonesia cabin crew". Zoel mentioned in his article published on Marketing.co.id entitled
Culture Themed Advertising, Giving "Brand" to the Brand stated that by slipping culture into advertising is expected to increase brand equity, be a differentiator among other products, make consumers more emotionally touched, and can be a bridge between consumers and products, and support national culture at the same time.

Therefore, the researcher examined the meaning of nonverbal signs, especially body language contained in Garuda Indonesia's television version of "Hands" and examined the audience's perception of the advertisement to find the results of the study whether the audience's perception of the aspect of the maker was in line.

\section{LITERATURE REVIEWS}

Broadcast media (broadcast media) which includes radio, television, film advertisements and other forms of video, are dynamic and purchased based on the amount of time (seconds, minutes), and appear shorter. Broadcast media messages, especially television, film advertisements, and other forms of video are different from messages delivered through print media. This is caused by the broadcast media involving the sense of hearing and vision in delivering the message so that it can cause more dramatic effects, entertain, attract the attention and feelings of the audience, turn on the story in it, create a strong brand image, generate trust in something that is shown, and effect music has an emotional effect and can intensify message 
memory through tone reps. (Moriarty, 2009:310311)

A primary sign system or primary sign system can be an element of a system that is more complete and has a different meaning than the original. That way, the primary sign is denotative while the secondary sign is conotative. This conotative concept is an important key to Roland Barthes's semiotic model (Wibowo. 2011: 16).

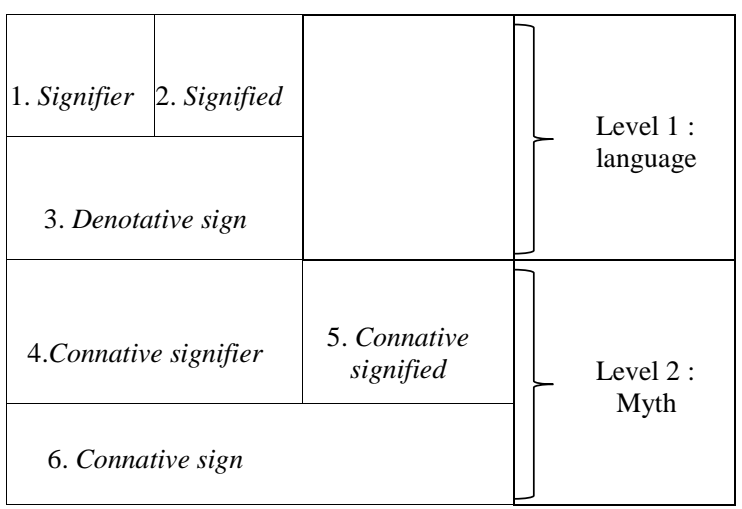

Figure 1 Sign Map Roland Barthes Source: Filsafat Semiotika (Rusmana, 2014:201)

From the Roland Barthes marker map above it appears that denotative sign (3) consists of markers (1) and markers (2). At the same time, however, the denotative is also a connotative marker (4).

Nonverbal messages are a form of communication using facial expression, limb movements, whole body movements, appearance, and more. According Jalaludin Rachmat in his book entitled Psychology Communication nonverbal messages are grouped into 5 types, namely: kinesik message, proksemik, artifaktual, paralinguistik, touch and bauan. (Ramdani, 2015: 6)

The Meaning of Body Language

Macro and Micro Expressions

1. Be happy / happy

Usually indicated by a smile. With the face of the cheek muscles move up and the edge of the lips to form a smile.

2. Angry / annoyed

Arising from discomfort or incompatibility with something. Can be seen from the side of the inner eyebrows together, narrowed lips, sharp eyes.

3. Sad

Arising out of disappointment or loss of something. Can be seen from facial expressions that lose focus, lips pulled down, eyelids droop.

4. Fear

It comes from an inability to overcome a thing. Viewed from both eyebrows rose simultaneously, open lips, eyelids tighten. a. Head Movement

1. Arm head

Has the meaning of rejection. In general, conveying the message "no", also means nonattraction to something.

2. Nod your head

It means universally agreed. Contains messages of hope, recognition, understanding, justification of a thing.

b. Hand gesture

1. Your palms are closed It means showing an authoritarian attitude, dominating, not wanting and should not be influenced.

2. Palms open

It is a form of acceptance, friendliness and trust.

3. Hand points

Show aggressive response, expose authority, disagreement.

4. Hold the arm

Is a form of adjustment, adjust emotions.

5. Hold the shoulders

Shows the form of support, compassion, sympathy.

c. Footwork

1. Meeting legs

Being puts respect towards the other person, indicates a limitation.

2. Direction of the foot to the outside

Demonstrates wanting to finish the conversation.

d. Body move

1. The position of the body is open

Shows openness, accepts advice, is happy with the topic of conversation.

2. Leaning on an object

Show adjustments with convenience when interacting.

3. Wearing

Shows the form of hard work, service, and earnestness.

4. Eyes closed

It means remembering, imagining, and thinking about a thing. (Ramdani, 2015: 27)

\section{PROBLEM STATEMENTS}

According to Susann Vihma and Seppo Vakeva in Visual Semiotics and Semantics of Products Introduction to Theory and Practice of the Application of Semiotics in Design (2009: 90) states that visualizing strategies as repeatable approaches is difficult. Personal interpretation can bring up very many variations in the category (nonverbal signs).

This reinforces that, not all audiences who watch advertisements can understand or have the same thoughts about the aspect of the advertiser. 


\section{METHODOLOGY}

To get good and correct results and data. Researchers perform qualitatively. Qualitative descriptive case studies are exploratory research and play a very important role in creating hypotheses or people's understanding of various social variables (Bungin, 2007:69)

\section{RESULTS OF ANALYSIS}

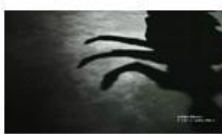

Scene 1

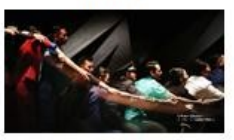

Scene 4

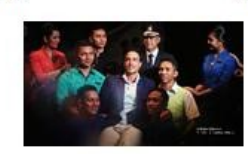

Scene 7

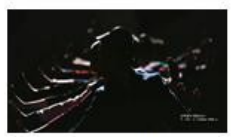
Scene 2

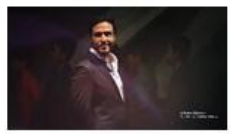

Scene 5

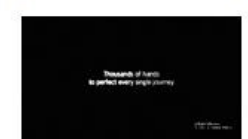

Scene 8
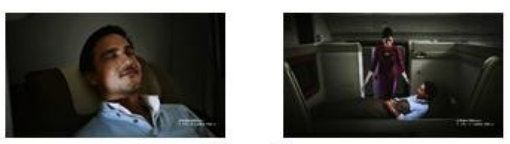

Scene 9

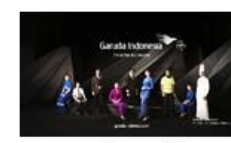

Scene 10

\section{a. Advertisement description}

At the beginning of the advertisement, there was a silhouette of a woman who stood stretching her hands on her side. Then a silhouette of three hands appeared stretched in sequence like forming a wing. Then came some women who perform dance moves wearing stewardess dresses typical of Garuda Indonesia and wearing clothing according to the color culture embraced by the company is green and some other colors with similar tones, such as: blue, purple, and red. Then this movement continued with movements like open flower petals which were carried out in sequence. Then came some other roles such as pilot, copilot, technician, as well as some other crew do wave forming movement while holding the opponent's elbow in front of him.

In the next scene, a male consumer actor appears by wearing a suit jacket that looks neat. Then the movement to form the waves by the Garuda Indonesia crew. Then the crew focused on the man. Some people carry the man and the rest hold each other's shoulders. There is a text "Thousands of hands to perfect every single journey" which means there are thousands of hands behind the perfection of travel with Garuda Indonesia. The next scene, the man enjoyed Garuda Indonesia's first class facilities. Here is seen a flight attendant who is serving a customer with hospitality. The final scene contains information about awards gained by Garuda
Indonesia and other information, such as product and program taglines being held.

\section{DISCUSSION}

This advertisement uses an emotional approach (soft-sell) and uses the type of dramatization ad execution that can be observed by the storyline displayed until it enters the message what it wants to convey in this ad. This "Hands" Garuda Indonesia advertisement has no narration (voice actor), this ad is only accompanied by background music because the thing that is highlighted in this ad is its visualization in delivering advertising messages. The background music contained in this ad is a supporting factor to strengthen the visual elements displayed. This ad chooses to use black background and lighting settings are made as dark as possible in order to create a dramatic and mysterious atmosphere. This ad also uses a low contrast image which gives the impression of peace, static and calm. In this advertisement, you can see the design principles in it as in scene 4 there are movements such as forming waves which in principle design are a combination of unity, balance and rhythm. Whereas in scene 1, the silhouette of a woman is a combination of emphasis and proportion in the frame. And in scene 3 , the movement of forming open flower petals is a combination of unity (rhythm), rhythm (rhythm), and proportion (proportion). At the beginning of the advertisement, there were several women who performed dance moves wearing flight attendants typical of Garuda Indonesia and dressed according to the color culture adopted by the company namely green and some other colors with similar tones, such as: blue, green, purple and red.

And some other roles wear black, white, and brown. Meaning of the meaning of color that is:

a. Red: brave, energetic, ambition, passion, love.

b. Green: harmony, calm, peace, grow.

c. Blue: trust, honesty, faithfulness.

d. Purple: supremacy, formal, imaginative.

e. Brown: serious, safe, awake, humble.

f. Black: expert, official.

g. White: clean, perfect, pure.

This advertisement has the function of nonverbal substitution messages, where verbal messages are replaced by delivery through nonverbal symbols. Based on the nonverbal marks found in scenes 4, 6 and 7, according to the symbolic code the movements holding hands and holding shoulders and shouldering are connotations of the manifestation of the unity, enthusiasm, cohesiveness, cooperation, loyalty, trustworthiness and high sincerity of Garuda Indonesia in serving the Indonesian and international community which is depicted through 
a group of people who move the body to form a wave and hold each other's shoulders.

This advertisement also uses cultural or cultural codes, especially displayed on aspects of dance and clothing by scenes 1 to 3 . The cultural codes displayed are movements that resemble dance movements and clothing that are used in Batik and Kebaya elements or motifs. The cultural code is seen in the visual mark where the performer wears traditional Indonesian (traditional) clothes, namely Kebaya and Batik. Where kebaya and batik are the typical clothes of the Java Island. This illustrates that Garuda Indonesia is an Indonesian national airline carrying high ancestral values by preserving culture into the formal or official (office uniform) of Garuda Indonesia. There is also a visual narration code that is displayed on scenes 7 and 9, where in the scene the character of a consumer closes his eyes and smiles while laying down. This tells the pleasure and relaxation felt when traveling using the services of Garuda Indonesia. In scene 8, a snippet shows the text "Thousands of hands to perfect every single journey" which means there are thousands of hands behind every perfect journey. The text is the main message you want to convey in this ad. In addition to the typographic elements displayed on scene 8, there are also typography of the slogan, logo, description of the website address and the award that Garuda Indonesia has obtained by SkyTrax. Typographic elements displayed in these two scenes use white Sans Serif fonts so that the typography contained in these ads can be seen clearly and so that they are clean and simple because the atmosphere displayed in this ad is dark in color. The use of Sans Serif letters is modern, simple, universal, stable, wise. From this analysis it can be concluded that the ad above with a visual sign of a group of people holding hands and then moving to form a wave is a sign that means unity, cohesiveness, cooperation, enthusiasm, earnest loyalty, and upholding the ancestral values that Garuda Indonesia is trying to portray in this advertising.

\section{CONCLUSION}

There are nonverbal signs holding hands and holding shoulders and shouldering means the realization of unity, enthusiasm, cohesiveness, cooperation, loyalty, trustworthiness and high sincerity as well as upholding the ancestral values that Garuda Indonesia tries to portray in this ad.

Garuda Indonesia managed to provide awareness about a good brand image, attract attention and concentration of the audience when viewing the advertisement, and managed to make the audience interpret the advertising message according to the results desired by advertisers. Although there are still some of the correspondents claiming they cannot understand the purpose of the advertising message.

\section{REFERENCES}

[1.] "Pendekatan Kualitatif \& Kuantitatif." Burhan Bungin. Bandung.Alfabeta. 2007

[2.] “Advertising Edisi Kedelapan.” Moriarty Sandra. Jakarta.Kencana Prenadamedia Group. 2011

[3.] “Gesture: Mengungkapkan Makna Di Balik Bahasa Tubuh Orang Lain dari Mikroekspresi Hingga Makroekspresi.” Ramdani Zaka Putra. Klaten PT. Hafamira.2015

[4.] "Filsafat Semiotika”. Rusmana Dadan. Pusaka Setia. Bandung.2015

[5.] https://www.tiket2.com/blog/inilah-iklan-terbaikmaskapai-penerbangan-indonesia/ Accesed on 28 April 2017 